\title{
THE HISTORIOLAE IN BELARUSIAN INCANTATIONS
}

\section{Tatsiana Valodzina}

Head of the Department of Slavic Folklore and Culture at the Research Centre of Belarusian Culture, Language and Literature of the National Academy of Sciences of Belarus

tanja_volodina@tut.by

\begin{abstract}
The article deals with one of the most popular techniques in Belarusian magical medicine - the so-called historiolae, the essence of which is to recall precedent situations. This implies that the "disequilibrium of being, which has arisen in human life at the present moment (e.g. a disease), is restored according to a sacred pattern that took place in the past". The texts declare connections between different levels of the worlds, past and present, but to the same extent between the microcosm and the macrocosm, erasing all distinctions between the real and the supernatural worlds. The present time of these charms prevents the transfer of the patient and the healer to ancient times of the myths. Instead, it is the sacred world that spreads around the requester. The most common form of such charms includes a narrative that relates certain events in Christian history, primarily describing the life of Christ or of one of the saints. A particular place among the narrative manifestations of historiolae is occupied by references to the Passion of Christ. These narratives, in turn, possess powerful life-affirming and healing potential. It is not the logical correspondence of a specific comparison in an incantation that is central, but the very desire to place the situation of treatment in an appropriate context. A number of texts from the author's field records and archival materials are introduced here into scholarly circulation.
\end{abstract}

Key words: traditional medicine of Belarusians, incantations, historiolae, precedent, Biblical images. 
The term historiolae has been widely used in western European scholarship to denote a type of charm or spell in which short mythological stories provide a paradigm for a desired magical action (Faraone 1988: 284). The term has been dominant in the German-speaking world as a more neutral term than the previously prevalent Analogieerzählung, a story by analogy, or Vorbilderzählung, a model story, as it allows for a broader interpretation (Schumacher 2000: 203). The historiolae exemplify the principle of similia similibus by placing charms "between a human dimension where actions are open-ended and a mythic dimension where actions are completed and tensions have been resolved" (Frankfurter 1995: 464) and describing the events that occurred during illo tempore, an indefinite time in the past. The historiolae aim to establish a connection between the mythological precedent and the present situation faced by the sufferer and their magical assistants. Mythic events are understood as archetypal: they retain their power forever, and this power can be used when they are repeated. Daniel James Waller offers a productive concept of considering the mechanism of using the historiolae as an echo when the healing effect is ensured by the repeated, modulated, and distinctive sounding of a sacred story (Waller 1988).

In East Slavic folklore studies, the term precedent is most commonly used. Drawing on numerous examples, Tatiana Agapkina convincingly reveals the magical functions of precedent-based situations as one of the most important tactics of a magical text:

"A reference to a precedent implies that the disequilibrium of being, which has arisen in human life at the present moment (e.g. a disease), is restored according to a sacred pattern that took place in the past. The regulation of both the present and the future is based on the past; it is from this past (in which sacred characters act) that examples of situations are drawn, the imitation of which is essential for correcting the present” (Agapkina [Агапкина] 2010: 612).

Relying on the definition of a situation of returning to mythic times for pragmatic purposes as "domesticated diachrony" (Claude Lévi-Strauss), on facts from different cultures, particularly German culture, Monika Schulz demonstrates how a return to the sacred and blessing atmosphere of mythic times becomes a peculiar kind of typikon of magical activity in the present (Schulz 2000: 292). The effect serves to blur the boundaries between the hu- 
man situation and the mythical dimension, sometimes in its most distant times of the creation of the world. Mircea Eliade repeatedly wrote about likening the earthly world to the sacred one when everything in the profanum world is created according to the models of the first times. The effect of the spell then lies in the re-actualisation of the mythic first time; as a model of any creation, the cosmogonic myth is able to help the patient start their life anew (Eliade [Элиаде] 1995: 34-43).

Allusions to the cosmogonic myth as a mythological precedent are also preserved in the magical texts. The doctor and the patient's appeal to the times of creation programme a return to the primordial time, a time with no diseases or troubles. The suffering person is recreated together with the world.

Шоў Госпадзі пайз сіняга мора, дунуў на свет, на свеці стала трава, на траве стала раса. Як сониэ ўзойдзе на свет, так $з$ травы раса спадзе $i$ з етага дзіиёнка уусё ліха спадзе... ${ }^{1}$ (Lopatin [Лопатин] 2017: 137)

God walked by the blue sea, He blew at the world, grass grew around the world, dew grew on the grass. When the sun ascends above the world, then the grass will lose its dew and all the evil will fall from this child....

The actions of a Christian character endowed with the functions of a healer are woven into the cosmographic picture of regulating the world:

Сягодня панядзелак. У панядзелачак вечарам Найсвенчая Матка па небе хадзіла, па небе хадзіла яснымі зарамі, яснымі зарамі з бельмі зубамі. Ясныя зоры патушыла, (імя) зубы загаварыла. Нябесныя зоры не гарэлі, каб у (імя) зубы не балелі. Яз духам, Бог з помаччу. ${ }^{2}$

Today is Monday. On Monday night, Holy Mother was walking in the sky, in the sky she was walking in bright stars, in bright stars with white teeth. She put out the bright stars, so [name] did not have a toothache. I am with the spirit, God with the help.

The charms demonstrate an orientation toward the cosmic order, which is mentioned in the following text by way of a reference to the origin of Man himself (through the recoding of the embryo and the new moon). Taking into account these "first" events, health should also be eventually restored: 
Млад маладзік нараждаеции ў цёмных начах, у вячэрніх зарах, не чуяў ён ні стукату, ні грухату, ні заносных лун да ні солнышка. Раб Мікалай у уттробе мацеры зараждаўся, не чуяў ён ні стукату, ні грухату, ні краснага сониа, ні яснага месяиа. Дай Госпадзі, штобы яго зубы не балелі і балезні у сабе ня імелі. Амінь (Bartashevich [Барташэвіч] 1992, No. 634)

The new moon is born in the dark night, in the stars of the night, it heard no rattle, no roar, no alien moons, nor any sun. Mikalai, servant of God, was born in his mother's womb, he heard no rattle, no roar, no red sun, no bright moon. Help him, oh Lord, so his teeth don't ache and have no disease inside them. Amen.

Obviously, the essence of this technique is also in declaring a connection between different levels of the worlds, the past and the present, and, to the same extent, between microcosm and macrocosm.

However, the most common kind of incantation of this type includes a narrative conveying the events of Christian history, primarily describing the earthly path of Christ or one of the saints. Although a historiola does not necessarily require a Biblical precedent or even its magical reinterpretation, it is the story of the miraculous intervention of Christ or his associates that acts as the most substantial role model. In the spell, an episode is presented to describe the positive resolution of a crisis. What follows is a reference to the person's painful condition (or, less often, an animal's) in this world, the healing of which is expected according to a sacred pattern.

Крэст на небі, крэст на зэмлі, крэст на мні. Спас Господь роскольніка на крысте, спасі Господі рабу твою (имярек) і мене. ${ }^{3}$

Cross in the sky, cross on earth, cross on me. The Lord saved the rebel on the cross, save, oh Lord, your servant (name) and me.

A historiola manifests itself most clearly in direct comparison, when the narrative part ends with a comparative construction, i.e. there is a comparison of the cases, conditions or attributes of the sacred character and the patient. There are such texts in Belarusian tradition, too, e.g.: 
Як Ісус Хрыстос на расп'яиі буў, з расп'ящия ўзняуся на небеса, усе замкі паламаў, (имярек) чарайніка, чарайніиу не дапускай) (Bartashevich [Барташэвіч] 1992, No. 85)

When Jesus Christ was on the cross, he ascended to heaven from the cross, he broke all the locks, did not allow wizard, witch to [name];

Як Сус Хрыстос із мартвых шоў, так залатнік на месиа ішой, як Ісус Хрыстос із мартвых устай, так залатнік на месиь ўстаў. Залатнік-залатнічок-старынькі дзядок, дзе быу ад малку, стань да старку. ${ }^{4}$

As Jesus Christ returned from the dead, so the zalatnik [the uterus and related diseases] returned to its place, as Jesus Christ rose from the dead, so the zalatnik rose to its place. Zalatnik, little zalatnik — a little old man, where you were from your birth, there you stand till you're old.

The structure of similia similibus essentially subjugates the narrative part of the spell to the directive statement, the part that says, "May it be as it was then" (Frankfurter 1995: 468). However, there are very few direct parallels or comparisons of the events of Biblical history and the healing situations in the corpus of Belarusian incantations.

Comparison is implicated in constructions of the type "sacred precedent, may the patient not have...", e.g.:

Першым разочкам, добрым часочкам Госпаду Богу памалюся. Маць Прачыстая па иэркві хадзіла, з-пад права рабра Iісуса Хрыста радзіла. Не баялася ні урроку, ні прасроку. Хай жа раба Божая (імя) не баіџиа. Бог з помашчу, ая з духам (Viarheyenka [Вяргеенка] 2013, No. 177).

In the first place, in the good time, I will pray to God. Most Holy Mother walked in the church, from under her right rib did she give birth to Jesus Christ. She feared no bad spell or hex. May the servant of God (name) have no fear. God is with the help, and I am with the spirit

Curiously, in the structure of the text itself, a historiola can also complete the narrative, follow the directive appeal to the disease, and then the appeal to the sacred events serves as a guarantee of healing. 
Патайнік, каласьнік, дваровы, сасновы, карчовы, рабінавы, асінавы. Стой, патайнік, каласьнік, пасылаю иябе на мох, на балаты, дзе людзі не ходзящь, сарокі не шчабечуць. Там табе піџь гуляиь, а етага патайніка ў (імя) не бываџь. Радзіусся Ісус Хрыстос, патайнік ізьнёс, Мачі Ісуса Хрыста раджала, беса праклінала, Маркавай рукой, усе ангель са мной. ${ }^{5}$

Epilepsy, falling evil, of the yard, of the pine, of the stump, of the rowan, of the aspen. Stop, epilepsy, falling evil, I am sending you to the moss, to the bogs, where people do not go, magpies do not chirp. There you will eat and drink, but (name) will not have this pain. Jesus Christ was born, he took the falling evil with him, Mother gave birth to Jesus Christ, cursed the devil, with the hand of Mark, all the angels are with me.

The historiolae organised around the baptism of Jesus Christ in the River Jordan, especially popular in the European fund of spells, is also common among Belarusians.

Стань крэвъ у рани, якъ вода въ Ирдани, кеды ксиивъ свентый Янъ, кеды ходзивъ Христосъ Панъ, аминъ (Romanov [Романов] 1891: 69, No. 94)

Blood in the wound, become like water in the Jordan, when Saint John baptised, when Lord Jesus walked around, Amen.

"Looking at the wound, cross oneself and say:

Пане Езу, нех в тэй ране кроў стане, як вада у Іярдане, дзе Пана Езуса хрысиілі. / Lord Jesus, may blood stop in that wound, like water in the Jordan, where Lord Jesus was baptised.

Then read the prayer "Our Father" and "Hail Mary" and then blow on the wound. Repeat this three times" (Vasilevich, Salavei [Васілевіч, Салавей] 2009: 39, No. 1815, Iŭje district).

In popular representation, St John the Baptist is easily replaced by the Mother of God or one of the saint characters, and it is not only water that mighy stop, but Christ too: 
Стой, крой, уране, як Ісус на Ярдані, як Матка Боска Ісуса Хрыста хрысиіла. ${ }^{6}$

Stop, blood, in the wound, like Jesus in the Jordan, like the Mother of God baptised Jesus;

Астанавіся, кроў на рані, як Ісус Хрыстос стаяў на Іярдані. Ісус Хрыстос иярпеў і крыві астанавіиฺиа вялеў. Амінь. ${ }^{7}$

Stop, blood, in the wound, like Jesus Christ stopped by the Jordan. Jesus Christ suffered and told the blood to stop. Amen.

However, it is much more common to witness the motif for baptism being implied, while there is a reference to stopping water, or even Christ himself, that becomes semantically significant and is thus expected to programme the cessation of bleeding.

Ішоў Ісус Хрыстос иераз раку Ардан. Астанавіўся Ісус Хрыстос пасярэдзіне Ардані, астанавіся крой у рані. Амінь (Vasilevich, Salavei [Васілевіч, Салавей] 2009: 373, No. 1776, Masty district)

Jesus Christ walked through the Jordan River. Jesus Christ stopped in the middle of the Jordan; stop, blood, in the wound. Amen.

Curiously enough, a number of Latin and German texts of the 15 th century with the motif of Christ in the River Jordan never mention baptism; it is the stopping of water that is semantically important (Ohrt 1938: 31). The dominance of plots with the motif of the sacred centre in local complexes and in the texts of this group match the sacred river with the mythological locus marked by the oak.

С-пад дуба караністага цякла Юрдань-рака, там ішоў Ісус Хрыстос і святая Ілля. Вадзяныя ключы закрываліся, Юрданьрака станавілася. Закрыйцеся, жылы крывавыя, стань, не цячы, кроў чырвоная. ${ }^{8}$

From under the rooty oak flowed the Jordan River, there were Jesus Christ and Saint Elijah. Water springs were locked, the Jordan River stopped. Stop, vessels of blood, do not flow, red blood. 
In the European traditions of various times, the situation on the River Jordan is included in many functional groups, not only in charms against bleeding (Ohrt 1938: 79). Belarusians, for example, have incantations 'for a fire':

Як Ісус Хрыстос на Арданской вадзе стаял, так стой, агонь, астанавісь на месие...

As Jesus Christ stopped in the water of the Jordan, so stop, fire, stop where you are...

and against sorcery. Perhaps, the texts of this group also reflect the motif of Moses crossing the Red Sea:

Ішоў Бог иераз раку Іардан, вялеў вадзе стащь. А я вялю крові стаць. Амін (Vasilevich, Salavei [Васілевіч, Салавей] 2009: 364, No. 1713, Dziatlava district)

God walked across the River Jordan, he ordered the water to stop. And I will order the blood to stop. Amen,

which is especially popular in the German charms tradition (Schulz 2000). The choice of characters and the organisation of events are often subordinated to the rules of poetic speech, including rhyme, alliteration, and so on, as in the formula-based text of:

Сьянты Ян ішоў праз Ярдан, вада стала, то і ты, кроў, стань. ${ }^{10}$

Saint John walked through the Jordan, water stood still, then you, blood, stand still.

The vast majority of the texts with the River Jordanian motif are recorded in the west of Belarus, in areas of primary residence of the Catholic population.

A special place among the renditions of the historiolae is occupied by the Passion of Christ. In the texts of various genres, the crucifixion and wounds of Christ (inspired by John 19: 34: "one of the soldiers pierced his side with a spear, and at once there came out blood and water" acquire the meaning of the redemptive sacrifice. According to Ernst, the water and the blood of Christ, as healing tools in verbal magic, are a metonymy of baptism and redemption. The motif was first found in a spell against arrows from a twelfth-century manuscript in the Vatican Library. In a free translation, the plot amounts to the 
following: Longinus was a Jew, he pierced the heart of our Lord Jesus, blood and water flowed from there. Water is our baptism, blood is our redemption (Ernst 2011: 76-77). See in later German records:

...Logemimuss (=Longinus), der blinde Jude, der stach Christus dem Herrn seine Seite durch und durch; daraus floss Wasser und Blut, das ist dem N. N. Für seine Augen gut. (Haase 1897: 54)

The image of Longinus in the German tradition is primarily characteristic of charms for bleeding, but is also found in other thematic groups. It is also important that the soldier received his sight, not only in the physical sense, but also came to believe in Jesus. Among Belarusians, the image of Longinus appears on a single occasion, and is related to the treatment of ocular diseases: "Here you'll wake up early, don't drink or spit, and cross yourself and say: 'Christ is Risen! Longinus the centurion, help me'. Take some spit from under the tongue and rub it in your eyes". ${ }^{11}$ Perhaps, indirectly, the situation was reflected in the incantation imperative of

Сьвяты Якаў, хапай кап’ё, затыкай, замыкай кроў ў рані. Амін, амін! $!^{12}$

Saint James, grab a spear, stop, lock the blood in the wound. Amen, amen!

The redeeming meaning of the blood of Christ is also found in the Belarusian texts:

Мамка мая, дабрадзея мая, ичі спіш иіі ляжыш изі адпачываеш? - Сплю, ляжу, адпачываю і уува сне сніциа. Няхай мой сон на дажджы падзе. На высокай гары на дрэве залаты хрэст, на хрысие Ісус Хрыстос распяты, раскрыжаваны, жалезнымі гваздамі папрыбіваны. Праз святое рабро кроў иячэ. Прышоўк яму Госпад на трэичі дзянёк, паставіў грабок, усяму свету аб 'яўленне, святому изельиу палягчэнне. ${ }^{13}$

My Mother, my patroness, are you sleeping or lying down or resting? - I am sleeping, lying down, and resting and having a dream. May my dream fall with the rain. High on a mountain, on the tree is the golden cross, Jesus Christ is crucified on the cross, spiked with iron nails. Blood 
is flowing through the holy rib. The Lord came to him on the third day, set him a coffin, revelation for the whole world, relief to the holy body. ... ияябе жыдові паймаўшы і на крэст ияябе распяўшы, назей і рукей $\kappa$ красту прыгваздзіуишы, иярновы вянок на галаву тваю святую вазлажыўшы і тваё рабро святое кап'ём прабіўшы, $i$ з твайго рабра сыйдзе крой $і$ вада. I Адам хрысиіусся тваёй крывёю (Vаsilevich, Salavei [Васілевіч, Салавей] 2009: 82, No. 275, Dziatlava district).

...the Jews caught you and crucified you on the cross, nailed your legs and arms to the cross, put a crown of thorns on your holy head and pierced your holy rib with a spear, and out of your rib blood and water will flow. And Adam was baptised with your blood.

In the Belarusian tradition, the theme of Christ's torment is included in the texts aimed at stopping bleeding.

Хрістос у иялніцы і на крест яго распіналі, капьём ребры прыбівалі, крой пускалі, свечкай прыпекалі. Ізноў крой зынімалыся, сунімалыся. Займіся і у рабы Божае (імя). Амін (Vasilevich, Salavei [Васілевіч, Салавей] 2009: 380, No. 1821, Krasnapollie district).

Christ was in prison and crucified on the cross, they pierced his ribs with a spear, let his blood out, seared it with a candle. And blood stopped again. Stop it in the servant of God (name). Amen.

A prayer for nosebleeds is known from the seventeenth-century handwritten doctor books: "And cross yourself three times with a knife and draw a line: «Откуду ти придет господь бог, копие приа в ребра свои, яко он не устрашился язвы, не режежеся, укорися у вяде, яко лоза» Очевидна книжная основа этих текстов. 'From somewhere, Lord God will come, a spear will take into his ribs, as he was not afraid of the wound, was not hurt"” (Redkiye Istochniki [Редкие источники] 1977: 113). The book origin of these texts is obvious.

The stigmata of Christ, mentioned in Gal. 6: 17, are used in many European spells for wounds, when they are credited with the ability not to bleed, fester or swell, although none of this is mentioned in the Biblical descriptions. The charm magically simulates both reality and the sacred event itself - out of 
compassion, the popular consciousness would like Christ not to be sick and his wounds not to hurt him. Particular emphasis, as conditioned by the pragmatics of the incantation, is extended to the invulnerability of the Body of Christ.

Як у нашага Ісуса Хрыста пяџь раначак, пяџь болечак. Раначка 3 раначкай сайдзіся, плахая кроуу у рабы Божай (імя) у (галаве, крыві, нагах) разыйдзіся, добрая астанавіся. Як нашаму Ісусу Хрысту y балезнях не бываць, так і нашай рабе Божай (імя) балезні не відаць (Vasilevich, Salavei [Васілевіч, Салавей] 2009: 378, No. 1809. Valožyn district).

As our Jesus Christ had five wounds, five sores. Come wound with wound, flow out, blood in servant of God (name), in her (head, blood, legs), stop, good blood. As our Lord Jesus Christ will not be in pain, so our servant of God [name] will not see diseases.

The idea of every human wound as the sixth wound of Christ, washed and redeemed by His blood, is rarely found in the East Slavic tradition (Agapkina [Агапкина] 2010: 369), e.g. in Belarus:

У Спасіщеля было 5 ран, а шо сстую язагаварываю (Shteiner, Novak [Штэйнер, Новак] 1997, No. 148, Homieĺ district).

The Saviour had five wounds, and I'm charming away the sixth.

In Belarusian incantations, an appeal to the holy wounds of Christ does not necessarily refer to the corresponding Biblical account, as the very mention of them attaches a specific tone and sacredness:

Госпадзі, прыймі маю малітву да святое раныл. Хрыстос радзіўся, хрысиіусся на Вердані. ${ }^{14}$

Lord, accept my prayer to the sacred wounds. Christ was born, baptised in the Jordan;

Ізусовы крэпкі раныл. Сонща ўсходзіџь $і$ заходзіџь, няхай таго ... цела боль праходзіиь. ${ }^{15}$

Christ's wounds healed fast. The sun is up and the sun is down, may this... body lose its pain. 
The episode of Christian history (John 19: 34), which formed the basis of the "Longinus formula", is well known in apocryphal texts, cf., in "The Virgin's Dream", known to Belarusians in hundreds of versions, ${ }^{16}$ e.g.:

На гарэ Сіянскай, на зямле хрысиіянскай

Там цฺэркаўка стаяла,

У той изэкаўкі Прысвятая Дзева Маці Марыя спала.

Відала ана сон дзіўныл-прадзіўны, страшны-прастрашны,

Як Хрыста на муку бралі,

На Крысие распіналі,

Цярновы вянок надзявалі,

Кап'ём рабро і рукі прабівалі.

Із-пад правага рябра лілася кроў $і$ вада

Усяму свету на стаянія, а людзям на помашч (Lapatsin [Лапацін] 2018: 262)

On Mount Zion, in the land of the Christians,

There was a church,

In the church the Blessed Virgin Mother Mary was sleeping.

She saw a most miraculous dream,

As Christ was taken to be tortured,

Crucified on the cross,

They put a crown of thorns on his head,

Pierced his rib and hands with a spear,

From under the right rib, there flowed blood and water

For the whole world to stand, and for the people to help.

The appeal to the resurrection of Christ, in turn, possesses a powerful lifeaffirming and healing potential. The Easter formula "Christ Has Risen" is a vivid example of the declarative type of ritual expression, which not only recognises, but also creates a certain reality. In Belarusian incantations, this formula can even be used in the form of a reinforcement:

Хрыстос васкрэс ад рабы(а) божай... Амінь(Vietka district) 
Christ is risen from the servant of God... Amen;

Мой дух, Гасподня помашч, Хрыстос васкрэс і уурок ісчэз (Žlobin district)

My spirit, Lord's help, Christ is risen, and the bad spell is gone.

The knowledge and understanding of Biblical events in incantations are sometimes accompanied by simple and even primitive analogies, for example with the birth of Christ:

Як Ісус Хрыстос на увесь свет явіууся. так і р.б. радзіўся, сонцам асвяиіуся і месяиам увязаўся, усімі святкамі саджаўся (Bartashevich [Барташэвіч] 1992, No. 1214, Homieĺ district).

As Jesus Christ manifested himself to the whole world, so the servant of God was born, illuminated by the sun and girt by the moon, with all the saints around him,

Or with His Resurrection:

Ісус Хрыстос васкрос, каб і.р. здароўе васкрасло (Bartashevich [Барташэвіч] 1992, No. 914)

Jesus Christ is resurrected, so may the servant of God's health be resurrected, etc.

The events of the sacred history are intertwined in mundane contexts, when even the disciples of Christ are compared with varieties of roses or the disease of rose (erysipelas):

Камяной дарогай Пан Езус ішой, ивет ружу Пан Езус нашой. У Пана Езуса дванащиаць учанікоў, а у розы дванациащь ивятой. ${ }^{17}$

Lord Jesus walked along a stone road, Lord Jesus found a flower of rose. Lord Jesus has twelve disciples and the rose has twelve colours.

Obviously, resorting to Biblical history, in turn, undergoes processes of adaptation and transformation that demonstrate the liberal handling of material for the historiolae, with a rather significant departure from the dogmatic seriousness required in relation to the Biblical word. In some cases, this process is 
forced to the level that it almost leads to a new concept of Biblical events, which, in turn, are then again used as initial evidence for subsequent magical practice (Schulz 2000: 357). Indeed, it is not always a question of establishing a similarity, but of creating a correspondence — sometimes a quite surprising one — between the two situations (Bozoky 1992: 89).

Божжая Мацірь на камені сядзела, Ісуса Хрыста дзяржала, тынам агараджала, піліной пілінала, а большы яна нічога ня знала, толькі знала урокі-улёкі адбаўляць палявыя, дамавыя, наносныля, намоўныя, прыгаворныя, суседнія, сямейныя. Із Ісуса Хрыста із ручак-із ножак гваздзё вынімала, на камені прыбівала, і етай рабе Божжай Ганні пакой давала, ціхінькі лёгінькі мой дух прынімала. Мой Дух - Гасподні Дух (Lopatin [Лопатин] 2017: 125).

Mother of God was sitting on a rock, holding Jesus Christ, guarding him with a fence, covering him with a shroud and she did not know anything else, just knew how to fight bad spells of the field, of the house, contagious, magic, sorcerous, from the neighbours, from the family. Out of Jesus Christ, out of his legs and arms, did she take out the nails, left them on the rock, and gave peace to this servant of God Hanna, accepted my quiet and light spirit. My Spirit — Spirit of the Lord.

The process is especially expressive in Belarusian incantations, as Biblical events are intertwined with fabulous motifs, and sometimes their logically incompatible and figuratively fantastic fusion produces a special effect. Obviously, the logical correspondence of a specific comparison is not essential, essential is the desire to place the treatment situation in an appropriate context.

The plot varieties of the historiolae form two equal blocks - when the action takes place in the sacred centre or the main assistant is on the way. It is someone, most often a Christian or even a mythological character, who is travelling; something happens to him or her, as a result of which (or in spite of) a recovery occurs. Analogy requires that the semantic levels of the text and reality be interconnected.

Ходыў Біг по зымлі і по воді і по всякой моџуы і ны бояўся суроцы, уроку, ляку і прыговору, ны урыкання, ны ўлякання. I ты, раб Божый (імя) ны бійся ны урроку, ны улляку. Амінь. ${ }^{18}$ 
God walked around land and water, and everywhere He could and he feared no bad spells, fright or a love spell, no hex or curse. And you, servant of God (name), fear no bad spell or fright. Amen.

The description of events in the sacred centre involving divine characters produces such a powerful healing effect that the entire cluster of texts does not require listing the person's inferiority or seeking help. They are only limited to stating the sacred order or the ability and willingness of the named character to come to the rescue.

Ехаў Юрый і Ягорый на вараном кане, у залатом сядле, па крутой гарэ, па сырой зямле, па зялёнай траве з трымя залатымі тростачкамі. Адна тростачка малая, другая залатая, а трэияя тая, што ўдары і вывіхі выгаваравае і вымаўляе па сіняму мору адпраўляе. ${ }^{19}$

St George was riding on a black horse, in a gold saddle, on a steep hill, on the damp ground, on green grass with three gold canes. One cane is small, the second is gold, and the third one is that charms blows and dislocations away and sends them off on the blue sea.

This cluster also includes a number of implementations of the plot of the Second Merseburg Charm:

Ехаў Ісус Хрыстос на вороном коне, на золотом седле ичераз калінавы мост.

Конь спатыкнуўса, а мост проволіўса, у коня сустаў звернуусса.

Мусіў Ісус Хрыстос з коня зьлязаць, сустаў настаноўляць.

Шкура на шкуру, а крой на кроў, а сустай на сустай, штоб удар $i$ зьвix nepacmay. ${ }^{20}$

Jesus Christ was riding on a black horse, on a gold saddle, through the bridge of Kalina.

The horse stumbled, and the bridge collapsed, and the horse's joint dislocated. Jesus Christ had to climb down from his horse, and fix the joint. Skin to skin, and blood to blood, and joint to joint, so the blow and the twist stopped. 
These and a number of similar texts report a precedent event with a favourable ending, without mentioning the patient, while the story is limited to information about the sacred character healing or his horse. No less widespread are texts involving a story told at the beginning of the incantation, preceding, conditioning, and introducing a final imperative formula.

Первым разам Гасподнім часам Госпаду Богу памалюсь, святой Прэчыстай пакланюсь. Ехаў Сус Хрыстос чэраз залаты масток, еслятко ступіло, ножку звіхнуло. Стоіт Ісус Хрыстос і плачэрыдае. Іде Прэчыста Матер Божа і кажэ:

- Сын мой вазлюбленны, чаго ты плачэщ-рыдаеш?

- Як мне не плакат не рыдат, ехаў чэрэз залаты масток, еслятко ступіло, ножку звіхнуло.

- Не плач, Сынку, не рыдай, я яму так зраблю, як яго маті параділа. Кость $і$ з костю складала, жылу з жылою стачыла, кроў $і$ з кроўю перэлівала.

Як сухому дубу не развіващия, так у крэшчэного (имярек) у нозі болі не буват ${ }^{21}$

For the first time, in God's time, I will pray to God, will bow to the Most Holy Mother. Jesus Christ was riding across a bridge of gold, his donkey stumbled, twisted its leg. Jesus Christ stopped, and started lamenting. There goes the Most Holy Mother of God and says:

-My dear son, why are you crying?

-Why can I not cry, I was riding across a bridge of gold, my donkey stumbled and twisted its leg.

-Don't you cry, Son, don't you cry, I'll make it look the way his mother bore it. Bone to bone, vein to vein, blood to blood.

As a dry oak will not grow, so the baptised [name] will have no pain in his leg.

The incantations of this type blur the distinction between the real and the supernatural worlds. The present time of these spells precludes the transfer 
of the patient and the healer to ancient, mythic times, and the sacred world spreads around the supplicant, instead.

In Belarusian charms, the historiolae are found in most functional groups, and occupya rather prominent position in some of them, e.g. in charms for easy childbirth. The main plot conflicts of childbirth charms are few, while the main motif for opening the birth canal is realised by various means. the special elevated tone and sacredness of this type of spells is imparted by the idea of comparing the pains of a woman in childbirth with the torments of the Virgin or even those of Christ. The European traditions of charms and the rituals of Christmas are saturated with numerous parallels between the figurativeness and ritualism of childbirth and those of Christmas, as the Virgin and the mother in childbirth are regularly compared (see in detail Strakhov [Страхов] 2003: 191-227). In childbirth charms, events occur simultaneously in Biblical time and the time of woman's labour, which by the mere fact of referring to the precedent, magically ensures a successful outcome in the childbirth:

Божжая мацер Суса Хрыста спарадзіла, сорак нядзель насіла, у божжай пасьиелі ляжала; к рабе божжай прыхадзіла і гэту боль адвадзіла, за повесьиі ў добрам месьиі станавіла (Bartashevich [Барташэвіч] 1992: 244, Mahilioŭ district)

Mother of God gave birth to Jesus Christ, bore him for forty weeks, lay in God's bed; came to the servant of God and took the pain away; Як Маць Прячистая у етом сама бувала, и Суса Христа у городзи у Русалими на руки принимала, и иарскія вороть расчиняла и рабе божой прощи давала, расступицеся, разыйдзицес, усе сиежачки, дорожачки, иарскія вороты. Быстрыя косьичи расступися, рабе божай Марьи разыйдзися (Romanov 1891: 160, No. 4)

As Most Holy Mother did it herself, and took Jesus Christ in her arms in the city of Jerusalem, and opened the Holy Doors and offered help; come apart all paths and tracks, the Holy Doors. Quick bones, ${ }^{22}$ come apart, in servant of God Maria, come apart.

Relevant in this context is the formulaic beginning of a charm from the Bierazino district, which should be repeated three times: 
Шчаслівая тая мінутачка, у якую Iсус Хрыстос нарадзіуся (Vasilevich, Salavei [Васілевіч, Салавей] 2009: 48)

Happy is the moment when Jesus Christ was born.

An effective magical tool expected to programme not only successful, but also painfulm childbirth is the precedent-setting situation of the Virgin's giving birth to Christ.

Як Мащь Марія Ісуса Хріста радзіла, не крічаўшыл, не станаўшы $і$ людзі не слыхаўшы, так імне памагі, сьвятая Багародзій, радзійь i не крічащь $і$ не станащь. Амінь. ${ }^{23}$

As Mother Mary gave birth to Jesus Christ, without a cry, without a moan, and people heard nothing, so help me, Holy Mother of God, to give birth to a child without a cry or a moan. Amen.

In addition to the verbal embodiment of the motif of the Mother of God's delivery, the ritualism of Belarusians has preserved references to the actionbased design, first of all, in the advice to give birth on straw (Piatroskaya et al. 1998: 62). An appeal to the Virgin Mary, who suffered no torments, was quite common in the spells of medieval Europe. In particular, it was recorded in the popular English medical book (Liber receptorum medicinalium), compiled in Latin by John of Arderne, but translated many times into other languages. Among the tips, including magical ones, there are texts for easy delivery:

To make a woman deliver a child quickly after a long labour. Bind this charm below the knee of the woman in labour while saying the Lord's Prayer and the Ave Maria. (...) When Christ was born his mother suffered no pain. (...) Christ calls you child + come out (...)"24 (Jones, Olsan 2015: 421).

\section{CHARACTERS OF CHRISTIAN HISTORY}

The precedential space and time of the Belarusian charms are inhabited by key characters from the Old Testament, among whom the most frequent are Adam and Eve, as well as King David; less common are Cain and Abel, Abraham, Sarah, Isaac, Noah, Solomon, and others. God, Christ, and the Virgin Mary occupy a special position; Archangel Michael, Saints George, Nicholas, Barbara, 
etc. play their roles in certain plot situations. The set of these characters is to some extent determined by the chosen Biblical subjects, however, a number of heroes may become part of rather arbitrary situations. In some cases, the choice of a character follows the goal of the charm, by correlating the legendary history of the saint with the problem itself. In particular, St Antipas helps to relieve toothache. Regional traditions are represented by their own heroes, for example, the Sož and the Dnieper river basins are marked by a frequent reference to the Kyiv-Pechersk Lavra reverends, more often Anthony and Theodosius together, which reflects the local tradition of their veneration.

Unexpectedly active in the charms is the anthroponym Adam. Saint Adam appears as a proper healer. It might be interesting to note that these plots speak about the heavenly times, before Original Sin had been commited:

I ты, соль, ияарыца, божая памашніца, і не я иябе буду даващь, i будзець иябе даваць святы Адам, і будзещь казачь: "Етай скачіні, краснай шарсціні, ад чэмеры помачы дам” (Bartashevich [Барташэвіч]1992, №. 212)

And you, salt, the queen, divine helper, and I will not give you, Saint Adam will give you, and he will say: "This cattle, the red fur, I will give help from chemer [disease specific to horses].".

And even as a substitute for Christ in the versions of "The Virgin's Dream":

Матка Святая пайшла у иээркаўку ды кругом прыстола тры разы хадзіла, легла ды й заснула. I прыйшоў Адамко-сынок і пытае: “Ці ты, матанька, спіш, иі ты так ляжыш?" (Vasilevich, Salavei [Васілевіч, Салавей] 2009: 253, No. 1177, Klieck district).

Holy Mother went to a little church and walked around the altar three times, and lay down and fell asleep. Then came Adam the son and asked her, “Are you asleep, Mother, are you just lying?".

Of even greater interest is that the charms tend to demonstrate the life of the first humans from birth to death. In particular, in charms for good childbirth, an unborn baby is named Adam or Eve:

Первым разам добрым часам, я к Розе пріступаю, Маиь Прячыстую на помашч прізываю. Маць Прячыстая пріступала, 
каму там помачы давала. Ці ты Ева, изі Адам, не дзяржы, Гасподзь, там. Ці ты Ева, иі Адам, не дзяржы Гасподзь там.

For the first time, in a good time, I will proceed to Rose, calling Most Holy Mother for help. Most Holy Mother appeared, gave help to someone there. Or you Eve, or Adam, do not hold it, o Lord, there. Or you Eve, or Adam, do not hold it, o Lord, there.

It is the child who is addressed in the charm "For the preservation of the foetus":

Іиоў Адам чэраз божы дом, чэраз дванащуцацуь замкой. Замкну етьл замкі і загавару, пакуля Бог народзіизь да уррэм'я, зялезныя тыны, камянная гара, тыл, дзіиятка, стой, пакуль твая пара. Дай Бог на nомач (Bartashevich [Барташэвіч]1992, No. 1099)

Adam was walking through the house of God, through twelve locks. I will lock up those locks and I will spell them, until God helps give birth in time, iron fences, a stone mountain, you, baby, wait until your time comes. God, grant us help.

In the healing contexts, the precedent situation of creating Eve from Adam's rib foregrounds the very moment of the creation of Adam, placing the sick person in the place of Eve. In this way, the archaic motif of the second, this time divine, birth is implemented:

Івана мацуі радзіла, па людзях не хадзіла, здароўем надзяліла. Івана Бог сатварыў з жоуттай косиі, Адамавага рабра, каб Івану было добра. Дзе сонейка западала, там і ліха прападала (Vasilevich, Salavei [Васілевіч, Салавей] 2009: 262, No. 1220, Liubań district).

Mother gave birth to Ivan, She did not go among people, gave him health. God made Ivan from a yellow bone, Adam's rib, so Ivan could be well. Where the sun sank, there the evil disappeared.

It is Adam and Eve who are the first married couple:

Штоб мы у пары жыли, вясялилися и добра гаварыли... Адам и Ева спарышыл, етай пары никто не нарушы (Polesskije zagovory [Полесские заговоры] 2003, No. 937) 
May we live as a couple, have fun and a good talk... Adam and Eve, the couple, no one will break this pair.

The incantations also mention the paradiasiac tree:

У прасветльмм полі стаіщь дрэва, пад тым дрэвам Адам і Ева. Як Адаму з Евай з раю не выхадзіиь, так етаму залатніку па жывату не хадзіць, не бушаващь і крэпка на сваім месцечку стаящь (Bartashevich [Барташэвіч] 1992, No. 814)

In the bright field, there stands a tree, under the tree, there are Adam and Eve. As Adam and Eve will not leave Eden, so this zalatnik will not travel around the stomach, will not rage, but firmly stay in its place.

The initial position of Adam and Eve in this text - the sacred centre under the tree - is generally consistent with the precedent, but is understood in the evaluation-based categories. Yet, the first people should become the first deceased:

Я прашу Плёскія кладбішча, первых занятых людзей Адама $і$ Еву. Прашу Мар'ю, Ганну, Пятра, старых і мальх, бывальх, прыхажальх, знакомых і незнакомых і усех святых. Прашу, хлебсоль прыміще, Ніне здароўе вярніце. 9 разой. Змыуйы ліцо вадой, выліць ваду у бок могілак. ${ }^{25}$

I ask the cemetery of Pliosy, the first late people of Adam and Eve. I ask Mary, Anne, Peter, old and young, experienced, outsiders, familiar and strangers and all the saints. I ask you, take bread and salt, give Nina her health back. (Nine times. Having washed the face, pour the water towards the cemetery.)

Accordingly, living in the other world led to their frequent mention in toothache charms:

Маладзік-маладзік, гдзе ты быў? - У Адама. - А былі людзі у Адама? - Былі. - А што яны ядзящь? - Камень. - А баляиь у іх зубы? - Не баляиь. Пускай у раба Божага Івана зубы тожа не баляиь. ${ }^{26}$ 
New Moon, New Moon, where have you been? —At Adam's. —And were there any people at Adam's? - There were some. - And what did they eat? - Rocks. — And did they have a toothache? — No, they didn't. May God's servant Ivan have teeth without pain, too.

In addition to this precedent status, the images of the primordial people in charms appear along with other sacred assistants in typical plot situations:

Паехай Адам на зялезных калёсах, пайёз урокі, падуманьні, згаворы па уусіх сёлах. Папоўскія, парабоусскія, панскія, иыганскія, татарскія, жыдоускія, франиузскія, германскія, аўстрэйскія, мышккавы, жабкавы, ужовы і камарковы. ${ }^{27}$

Adam went on an iron cart, took bad spells and charms to all the villages. Of priests, of workers, of lords, of Gypsies, of Tatars, of Jews, of French, of Germans, of Austrians, of mice, of frogs, of water snakes and of mosquitos;

Перэход, перэход, сколькі иебе год? Казаў Адам і Ева, што ты тут не трэба. ${ }^{28}$

Falling evil, falling evil, how old are you? Adam and Eve said you are not needed here.

Significantly, the anthroponym of Adam itself acquires a wide range of meanings. Along with the name of the first man, it begins to denote the name of the fundamental element - the earth:

Добры вечар табе, земля Адам, ты, вада Арданне, ты од свету прыбываеш в калодезя и в реки наполняеш, паполни маю семейну жызнь любовью...29

Good evening to you, Adam the earth, you, the water of the Jordan, you come to the wells from very beginning and fill the rivers, fill my family life with love...

Curiously enough, the character of the sparrow, which was discouraged from damaging the crops, acquires the name of Adam, the fact most likely relying on consonance: 
$T b l$, верабейка Адам, я табе загона свайго не дам (Bartashevich 1992, No. 67) - You, Adam the sparrow, I won't give you my lot.

It is equally curious that the name of Eve is used to mark both the sacred assistants and a number of their antipodes. Within a single text, Eve appears as a holy helper and as the eldest among the twenty-seven sisters, the stars:

Вада-вадзіща, иарыца Улляніца-румяніца! Прыбаўляесся ты із гор, із вод, із вялікіх ключоў, прыбаў ты, Госпадзі і матар Божая, святая ияарыца Бугуродзіџа, етай скаиіні малачка. I зоры зарыиы, ёсиь трыдзевяиь сястрыцы, між вамі ёсиь большая сястрыца Ева. Святая Ева, святы Восіп, пашліия вы сваіх слуг шукаиі етыя скаціны малачка... (Bartashevich [Барташэвіч] 1992, No. 264).

Water-water, queen Ullianitsa! From the mountains you swell, from the waters, from the great springs, swell milk in the cattle, you Lord and the Mother of God, Queen of Heaven. And the stars, the twenty-seven sisters, among you there is the eldest sister, Eve. Saint Eve, Saint Joseph, send your servants to find milk for this cattle....

In one charm, Eve is the name of the snake queen (Romanov [Романов] 1891: 111) or the water snake's wife:

Вуж, вуж, добрымуж, твая жонка Ева, Ева, Ева. Садзяржай сваіх дзячей, бальшых і маленькіх і самых пасьледніх... ${ }^{30}$

Water snake, water snake, a good husband, your wife, Eve, Eve, Eve. Support your children, big and small, and the last ones...

or simply of a snake that bit someone:

Гадзіна Ева, сухая как дрэва, чого ж ты разозліласа, чого ж ты покусіласа... ${ }^{31}$

Eve the snake, dry as wood, why are you mad, why did you bite....

Of particular note is the group of texts in which Eve is described as the mother of all illnesses and placed in the mythological centre of the anti-world, the world of sickness: 
Удару, удару, гаспадару! Парадзіла иябе Ева на сінім моры, на бельм камені, там табе піваџі, ядаці, у Параскі не бываџь, касией не ламащь... (Bartashevich [Барташэвіч] 1992, No. 529).

Blow, blow, oh Lord! Eve gave birth to you in the blue sea, on a white rock, there you will eat and drink, will not be at (name)'s place, will break no bones....

The Belarusian spells have numerous mentions of Eve as the mother of illnesses, especially of dislocations and other limb injuries, e.g.:

Звіхава мачі, ударава маџі, увяродава мачі па садочку хадзілі, галубак шукалі. Галубкі знайшліся, каб костачкі, сустаўкі ўместа сыйшліся ${ }^{32}$

Mother of twist, mother of blow, mother of sprain walked in the garden, looking for doves. The doves were found, so the bones and joints came together.

Cases referring to Biblical characters as to the "parents" of illnesses are not unique. Even Jacob-Isaac, a character twinned in line with the mythological striving for two-ness, is declared the father of the saint (!) daughters who give shivers to the heart, make hands and feet numb and brain dry:

На востраве на камні там стаіщь прастол. За прастолам сядзіщьь Якаў-Ісакаў, і са святымі дачарамі, каторыя хадзілі сэриза знабілі, рукі ногі атыммалі, у галаве мозгі высушалі.

Прыехаў Юр'я-Ягор'я на вараным кані і з залатымм мячом.

- Якай-Ісакаў, адвядзі сваіх дачарэй, штоб яны не хадзілі, жывата не сушылі, рукі-ногі не ламілі, у галаве мазгі не атнімалі. Як не будзеш іх увадзіџь, буду мячом рубіиь і агнём паліџь. І у гэты час амінь. Эта ад уроку. ${ }^{33}$

On an island, on a rock, there stands a throne. Jacob-Isaac is sitting on the throne, and with his saint daughters who gave shivers to the heart, made arms and feet numb and brain dry.

St George came on a black horse with a golden sword. 
- Jacob-Isaac, take your daughters, so that they did not go around, make no belly dry, no arms and legs ache, no brain numb. If you do not take them, I will fight with my sword and burn with fire. And for this time, Amen. This one is for bad spells.

The incantations of the Polesia region preserve a motif involving the daughters of a sacral character included in a countdown structure. Most typical is Samson:

У Самсона было сім дочок. Із семі шысс, із шысты пять, із пяті штырыры, із штэрых тры, із трох дві, із двох одна, ропала вона, хай i врокы пропадають. ${ }^{34}$

Samson had seven daughters. Of the seven six, of the six five, of the five four, of the four three, of the three two, of two one, she is gone, so may the spells be gone.

Researchers have documented a number of texts about the daughters of the Virgin Mary (in a spell against a snake bite (Bartashevich 1992, No. 624) or Jesus Christ, who "walked in the mountains, led the twelve daughters with him".

The story of Cain and Abel takes a prominent place in the cluster of the Belarusian aetiological legends for the spots on the Moon, with the Earth's satellite standing for the place of punishment and disgrace, which arises from the main theme of these legends: fratricide. The topic of fratricidal murder is typical of many European traditions, e.g. one of the many Belarusian examples: "They say Cain killed Abel, a brother killed his brother. Cain is a sinful man. God revealed the murder on the Moon, so that people were afraid to kill" (Avilin, Bohaneva 2016: 114). In the system of medical magic, these Old Testament characters took their place among the toothache charms.

Каинъ, Каинъ, Каинъ, вяли спрасить брата сваяго Авиля, ичи балять ли у яго зубы. - „Неть“. - Такъ и у р. Б. неть. Ва имя Атияа и Сына и Святага Духа. Аминь, аминь, аминь (Dobrowolski [Добровольский]1891, No. 3)

Cain, Cain, Cain, tell them to ask your brother Abel if he has a toothache. - No. - So the servant of God has none. In the name of Father and of the Son and of the Holy Spirit. Amen. Amen. Amen; 
Каін! Каін! Каін! Спытай у брата свайго Авеля: не балящь у яго зубы? - Не. - Так бы у раба Божага (імя), не. Амін. Амін. Амін (Vasilevich, Salavei [Васілевіч, Салавей] 2009: 401, No. 1939, Iŭje district)

Cain! Cain! Cain! Ask your brother Abel: Does he have a toothache? -No. - May God's servant (name) have none. Amen. Amen. Amen.

Perhaps this configuration was conditioned by the dominant position of the Moon as the somatic equivalent of a tooth.

In every instance, allusions to the legendary story contribute to the formation of spells, in this case for epilepsy:

У полі пяску не перемеріщь, у морі вады не перялічь. Так Кайлю Авелю на месяцы не стаяць, у маладзениа спужанага маладзениа не бываиь. ${ }^{35}$

One cannot measure sand in the field, pour water from the sea. So Cain and Abel will not stand on the Moon, the frightened baby will have no fright.

In rare cases, one can find the names of Abraham and Sarah, both popular in incantations due to consonance, rather than relying on a precedent.

Оиець нашъ Аўрамъ усё поля узорав, жана яго Сара по полю ходзила, тьвятыеты садзила. А хто их копавъ, тому Богъ помогавъ (Romanov 1891: 103, No. 262).

Abraham, our Father, ploughed the field, his wife Sarah walked in the field, planted those beautiful flowers. And those who dug them had help from God.

Abraham is mentioned among the holy helpers:

Святы Абрам, святы Іван, святы Адам, прыйдзеце, з (імя) чорна гора забярэие, у сухі дуб занясеие, дзе вецер не вее, дзе сониа не грэе, дзе месяи не ходзіиь, дзе ніхто не ходзіиь (Bartashevich [Барташэвіч] 1992, No.1247). 
Saint Abraham, Saint John, Saint Adam, come, take black evil from [name], put it in a dry oak, where the wind does not blow, where the sun does not shine, where the Moon does not go, where no one walks,

as well as the name of a demonological character, though in the function of an assistant.

Як на моры Кіянскам, на гарэ на Сіяньскай, ранняя зара, вячэрняя зара, Абрамя, Храмя Ляксеевіч, і ты, Мар'я Хвёдараўна, упрашаю вас, умаляю, не сам сабою - кроую сваёю, прашу вас нахлеб, на соль, із жаной, із дзеткамі (Bartashevich [Барташэвіч] 1992, No. 970).

Once on the Sea of Kijanskaje, on Mountain Zion, a morning star, an evening star, Abraham, Khramia Liakseyevich, and you, Maria, daughter of Khviodar, I beg you, not by myself - with my blood, I ask you for bread, for salt, with my wife and my children.

Apparently, it was rhyming that led to the appearance of Joseph and Mary: Марыя, Іосіп звіх і ўдар разносіиь (Bartashevich [Барташэвіч] 1992 № 535): Maria and Joseph, twist and blow dosing. King David, and his principal and permanent attribute of meekness, is often referred to in the set opening of a prayer "O Lord, remember David, and all his meekness":

Памяні, Госпадзі, ияара Давыда і усюю кротась яго, і вялікую памяиь яго. Судзяржаў ичар Давыд ваду і зямлю, судзяржай жа раба Якімава ружжом (Bartashevich 1992, No. 4).

Remember, O Lord, King David and all his meekness, and his great memory. King David held water and land, so hold Yakim's gun;

Цар Давыд скрапіў неба і зямлю, зоры і ясны месяи, скрапі, Госпадзі, маю просьбу (Bartashevich 1992, No. 105).

King David sealed heavens and the Earth, the stars and the bright Moon, seal, O Lord, my request.

Perhaps, David's role as victor over the giant Goliath indirectly contributed to the north Belarusian motif of a war journey: 
Ехаўкруль Давід да Бога на вайну. Як табе, Давід, Бога не ваяващь, так табе, звіх, касьиі не ламаць. Выгавараваю з трох да дзевяиі, Бог да памоиь і я сама. ${ }^{36}$

King David was going to wage war on God. As you, David, will not wage war on God, so you, sprain, will break no bones. I count from three to nine, God will help and I myself.

David's royal position was in demand in texts which deviate a lot from the Biblical account, such as the following:

Было у ияара Давыда сем валоў, сем бугаёў. Сеў ияар на крэсле, стань, сустай, на месие. ${ }^{37}$

King David had seven oxen, seven bulls. The King sat down on a chair, stand, joint, on the place.

In general, the Belarusian material confirms and once again exemplifies the findings of Tatiana Agapkina: "Another peculiarity of this precedent-setting time is the fact that, although some events taking place in its framework reduplicate relatively accurately the facts of Biblical history, in the majority of these prayers and incantations, Biblical events are of symbolic interpretation, and even radically change their meaning; sometimes, incantations and apocryphal prayers simulate a different reality, the magical meaning of which, apparently, is conditioned by the nature of the precedent-setting essence of names and characters involved in them; finally, in other cases, this precedent time, and the reality created in it, become virtual, because the same events - due to variation, verbal game, etc. - appear and are perceived in different ways"38 (Agapkina 2010: 612).

The popularity of the historiolae strategy in Belarusian incantations is based on fundamental philosophical traits, which are characterised by the underlying unity of the world, the close relationship of all elements of the universe. "Assistance from powerful forces is a key peculiarity of the Belarusian incantations... An appeal to another person conditions the appearance of numerous actors, both of the highest rank (the saints), and the secondary, actively involved in the abolition of a disease" (Zavyalova 2006: 194). It is also important that the disease itself, which is conventionally explained as something alien, superfluous and relating to otherworldliness, occupies a corresponding position in the 
whole picture of the world, possessing its own self-contained portrait, which determines the strategy of communication.

The historiolae are not evenly distributed in the Belarusian ethnic territory, but pattern according to the functions of charms and local specifics, and in certain cases, they reveal obvious leitmotifs and goals. To a large extent, this is a result of whether the tradition is part of Slavia Orthodoxa or Slavia Latina. In particular, an appeal to Holy Scripture, including references to a separate account, is much more common in the western part of the country, in those cities densely inhabited by the Catholic population. First of all, it concerns the involvement in the magical texts of the theme of Christ's Passion and Resurrection. Among the west Belarus charms, there are sporadic references to the wounds of Christ and the retelling of his life, unique for the Belarusian ethnic territory, but quite common and popular in Western Europe. The Old Testament characters, often in fabulous surroundings, appear in the east Belarus charms.

Researching the historiolae in different ethno-cultural regions of the country and the comparison of records made in different periods (the period of official atheism and revitalisation of religious life) provides fruitful material for the study of religious behaviour "practiced away from the literate institutional religion of formal theology" (Waller 1988: 264). In any case, the historiolae serve as both a model of human healing and a set of case studies, but, most importantly, as a guarantor of the recovery of lost harmony.

Translated from Belarusian by Kanstantsin Staradubets.

\section{ABBREVIATIONS}

ABSU - the Archive of the Education and Research Laboratory of Belarusian Folklore of the Belarusian State University.

AHH - the Archive of the House of the Herbalist in the village of Strelna, Ivanava District.

AIASEF - the Archive of the Institute of Art Studies, Ethnography and Folklore of the National Academy of Sciences of Belarus.

APSU - the Archive of the Polack State University. 


\section{NOTES}

${ }^{1}$ Hereinafter, quotes from oral spells are given in italics. Omitted text before and after the quoted passage is not marked.

${ }^{2}$ ABSU: 1982, Vierbavičy village, Naroŭlia district, A.K, b. 1924.

${ }^{3}$ AIASEF: 2017, Biaroza district, AV, b.1928.

${ }^{4}$ AIASEF: 2007, Slabada village, Ušačy district, TK, b. 1935.

${ }^{5}$ AIASEF: 2009, Akciabr village, Žlobin district, NH, b. 1931.

${ }^{6}$ AIASEF: 1987, Pierašary village, Valožyn district, MD, b. 1920.

${ }^{7}$ AIASEF: 2003, Lukonica village, Zeĺva district, MZ, b. 1930.

${ }^{8}$ AIASEF: 1995, Barysaŭ sity, R.J., b. 1930.

${ }^{9}$ ABSU: 1991, Zabalaccie village, Mscislaŭ district, VS, b. 1908.

${ }^{10}$ AIASEF: 1999, Douhaje village, Ščučyn district, AZ, b. 1917.

${ }^{11}$ AIASEF: 2011, Mochaŭ village, Lojeŭ district, MA, b. 1933.

${ }^{12}$ AIASEF: 2015, Sielišča village, Vierchniadzvinsk district, VA, b. 1920.

${ }^{13}$ ABSU: 2006, Uhrynki village, Ušačy district, NR, b.1926.

${ }^{14}$ AIASEF: 1989, Pasiničy village, Slonim district.

${ }^{15}$ ABSU: 1984, Čaropki village, Hlybokaje district, VL, b. 1905.

${ }^{16}$ See East Belarusian recordings in Lapatsin [Лапацін] 2018.

${ }^{17}$ APSU: 2009, Tumilavičy village, Dokšycy district, TV, b. 1936.

${ }^{18}$ AHH: 1975, Starasiellie village, Ivanava district, FB, b.1897.

${ }^{19}$ AIASEF: 2008, Hubičy village, Buda-Kašaliova district, MP, b. 1937.

${ }^{20}$ AIASEF: 2011, Dubrova village, Lieĺčycy district, AA, b. 1931.

${ }^{21}$ AIASEF: 2017, village Brahin district, AB, b. 1930.

22 'Quick bones' refers to the pelvic skeleton, where 'quick' denotes 'moving'; the 'quick bones' are the bones that can move and let the foetus out.

${ }^{23}$ AIASEF: 2012, Mysavoje village, Kasciukovičy district, RK, b. 1930.

24 "Ut mulier paret cito infantem que diu laborat. ligetur istud carmen infra genua mulieris parturientis cum oration dominica \& salutacionem beate virginis + Sicut vere credimus quod verbum + caro + factum est. + et quod maria virgo deum peperit infantem deum verum $\&$ hominem. Sic $\&$ tu ancilla maria intercedente $\&$ domino magistro Jesu christo iubente feliciter. parias prolem quam in utero habes. Quando christus natus est nullum dolorem eius mater passa est. Denuo christus deus \& homo nascitur. + infans te 
vocat christus + exi + exi + christus vincit + christus regnat + christus imperat + christus te ab omni malo defendat amen. + michael + gabriel + Raphael + venite in adiutorium ei." ${ }^{25}$ ABSU: 1984, Tamary village, Babrujsk district, NŠ, b. 1912.

${ }^{26}$ AIASEF: 2018, Sanuki village, Jeĺsk district, MČ, b. 1933.

${ }^{27}$ AIASEF: 2010, Ščytkavičy village, Staryja Darohi district, FS, b. 1924.

${ }^{28}$ AIASEF: 2011, Lipliany village, Lieĺčycy district, AL, b. 1929.

${ }^{29}$ AIASEF: 2018, Telman village, Brahin district, NF, b. 1924.

${ }^{30}$ AIASEF: 2008, Chizau village Karma district, MS, b. 1933.

${ }^{31}$ AIASEF: 2011, Salihorsk, PI, b. 1925.

${ }^{32}$ AIASEF: Tuča village Klieck district, NK, b. 1923.

${ }^{33}$ AIASEF: 2009, Akciabr village, Žlobin district, NH, b. 1931.

${ }^{34}$ AIASEF: 2007, Psyščavavillage, Ivanava district, LB, b. 1937.

${ }^{35}$ AIASEF: 1989, Kniazejka village Mahilioŭ district, LM, b. 1918.

${ }^{36}$ AIASEF: 2019, Kamai village, Pastavy district, LK, b. 1940.

${ }^{37}$ AIASEF: 1999, Barysaŭ sity, MH, b. 1936.

38 «Особенностью этого прецедентного времени является также и то, что, хотя некоторые происходящие в рамках его события и воспроиз ᄀводят относительно точно факты библейской истории, в большинстве случаев в молитвах и заговорах эти библейские события получают символическое толкование и даже в корне меняют свое значение; инолгда заговоры и апокрифические молитвы и вовсе моделируют иную реальность, магический смысл которой, по-видимому, обусловлен исحключительно прецедентным характером задействованных в ней имен и персонажей; наконец, в других случаях это прецедентное время и создаваемая в нем реальность приобретают виртуальный характер, ибо одни и те же события - благодаря варьированию, словесной игре и т.д. - выглядят и воспринимаются по-разному».

\section{REFERENCES}

Agapkina, Tatiana 2010. Vostochnoslavjanskie lechebnye zagovory v sravnitel'nom osveshchenii. Sjuzhetika i obraz mira [East Slavic healing words in comparative coverage. The plot and the image of the world]. Moskva: Indrik.

Avilin, Cimafej and Boganeva, Alena 2016. Pljamy na mesjacy: belaruskija interpretacyi [Spots on the Moon: Belorus Interpretations]. Belaruski fal'klor: matèryjaly $i$ dasledavanni [Belarusian folklore: materials and researches]. Vol. 3: 112-149. 
Bartashevich, Galina. 1992. Zamovy [Incantations]. Minsk: Navuka i tehnika.

Bozoky, Edina 1992. Mythic Mediation in Healing Incantations, In Sheila Campbell (ed.), Health, Disease, and Healing in Medieval Culture, Houndsmill: Macmillan, pp. 84-92.

Dobrovol'skij, Vladimir 1891. Smolenskij etnograficheskij sbornik [Smolensk ethnographic collection]. 1. Sankt-Peterburg: Emel'janov. Zapiski imperatorskogo Russkogo geograficheskogo obchestva po otdeleniju etnografii, 29.

Eliade, Mircea 1995. Aspekty mifa [Aspects of the myth]. Moskva: "Invest-PPP".

Ernst, Wolfgang 2011. Beschwörungen und Segen. Angewandte Psychotherapie im Mittelalter. Köln/Wien: Böhlau.

Faraone, Christopher A. 1988. Hermes but No Marrow: Another Look at a Puzzling Magical Spell. Zeitschrift für Papyrologie und Epigraphik, 72: 279-286.

Frankfurter, David 2001. Narrating Power: The Theory and Practice of the Magical Historiola in Ritual Spells, in Marvin Meyer and Paul Mirecki (eds), Ancient Magic and Ritual Power. Leiden: Brill, pp. 457-476.

Haase, K. E. 1897. Volksmedizin in der Grafschaft Ruppin und Umgegend. Zeitschrift des Vereins für Volkskunde, 1897, pp. 53-74.

Jones, Peter Murray and Olsan Lea T. 2015. Performative Rituals for Conception and Childbirth in England, 900-1500. Bulletin of the History of Medicine, 89(3): 406-433.

Lapacin, Genadz 2018. "Son Bagarodzicy” y̌ pobytavaj i rèligijnaj praktycy žyharoy̆ Gomel'skaj voblasci [Dream of the Virgin" in everyday and religious practice of the Gomel region]. Belaruski fal'klor: materyjaly i dasledavanni [Belarusian folklore: materials and researches]. Minsk, Vol. 5: 248-287.

Lopatin, Gennadi 2017. Zagovory Vetkovskogo rajona Gomel'skoj oblasti [Incantations of the Vetka district of the Gomel region]. Palaeoslavica, Vol. XXV, 1 (2): $178-221$.

Ohrt, Ferdinant 1938. Die ältesten Segen über Christi Taufe und Christi Tod in religionsgeschichtlichem Lichte. Det Kgl. Danske Videnskabernes Selskab. Historisk-fllologiske Meddelelser. København, XXV, 1.

Polesskie zagovory 2003. Agapkina, Tatiana and Levkievskaya, Elena and Toporkov, Andrei. Polesskie zagovory (v zapisjah 1970-1990-h gg.) [Polesky incantations (in the records of the 1970-1990s]. Moskva: Indrik.

Pjatroy̆skaja, Galina 1998. Радзіны: Абрад, песні. [Families: Rite, songs] Minsk: Belaruskaja navuka.

Redkie istochniki po istorii Rossii 1977. Bochkareva, Z. N. (ed.). Drevnerusskij lechebnik. Perevod s pol'skogo XVI v., spisok XVII v. [Rare sources on the history of Russia 1977. Old Russian medical book. Translated from Polish XVI century, list of XVII century]. Moskva: Nauka. 
Romanov, Evdokim 1891. Belorusskij sbornik [Belarusian collection]. 5th ed. Vitebsk: Tip. Malkina.

Schulz, Monika 2000. Magie oder die Wiederherstellung der Ordnung. Frankfurt am Main: Peter Lang.

Schumacher, Meinolf 2000. Geschichtenerzählzauber. Die Merseburger Zaubersprüche und die Funktion der historiola im magischen Ritual, in Rüdiger Zymner (Hg.), Erzählte Welt - Welt des Erzählens. Festschrift für Dietrich Weber. Köln: Edition Chöra, pp. 201-215.

Shteiner, Ivan and Novak, Valjancina 1997. Tajamnicy zamoy̆naga slova [Secrets of the incantations]. Gomel': Belaruskae Agenctva navukova-tehnichnaj i dzelavoj infarmacy.

Strahov, Aleksandr 2003. Noch' pered Rozhdestvom: narodnoe hristianstvo i rozhdestvenskaja obrjadnost' na Zapade i u slavjan [The night before Christmas: folk Christianity and Christmas rituals in the West and among the Slavs]. Palaeoslavica XI. Supplementum 1.

Vasilevich, Uladzimir and Salavej, Lija 2009. Zamovy [Incantations]. Minsk: Belarus. Waller, Daniel James. 2015. Echo and the Historiola: Theorizing the Narrative Incantation. Archiv für Religionsgeschichte 16 (1): 263-80.

Vjargeenka, Svjatlana 2013. Gajuchae slova rodnaj zjamli (belaruskija lekavyja zamovy) [Healing words of the native land (Belarusian medicinal incantations). Fal'klorna-etnagrafichny zbornik [Folklore and ethnographic collection]. Gomel: Bark..

Zavyalova, Marija 2006. Balto-slavjanskij zagovornyj tekst: lingvisticheskij analiz $i$ model' mira. Moskva: Nauka.

\section{$\mathrm{BIO}$}

Tatsiana Valodzina, Ph.D., is Head of the Department of Slavic Folklore and Culture at the Research Centre of Belarusian Culture, Language and Literature of the National Academy of Sciences of Belarus. Main interests: folklore, traditional knowledge, folk medicine, charms and incantations, belief narratives, witchcraft, vernacular religion, traditional agricultural calendar. She is the sole, or co-author, of seven books, including Human Body: Words, Myth, Ritual (2009) and Folk Medicine: Ritual and Magic Practice (2007). Initiator and Editor-in-Chief of the collection of scholarly articles "Belarusian Folklore: Materials and Research" (published since 2014, 1 issue per year).

ORCID: G-8243-2012, https://orcid.org/0000-0002-9800-2199 